\title{
Understanding and Litera Legis of Marriage Law in the Millennial Era for School Children
}

Pujionio Pujiono ${ }^{1}$, Arif Hidayat ${ }^{2} \odot$, Dewi Sulistianingsih ${ }^{3 \odot}$ 1,2,3 Faculty of Law, Universitas Negeri Semarang, Indonesia Corresponding author: pujiono@mail.unnes.ac.id

Abstract: In Indonesia, the marriage law is regulated in UU No. 1 of 1974 which has been amended to become UU No. 16 of 2019. In addition, nonMoslems may comply with the provisions of the marriage law contained in the Civil Code. Marriage is an initial process for the formation of family life and the beginning of the manifestation of forms of human life. The daily life of men and women, created by God Almighty, naturally has an attraction to one another to share affection in realizing a life together or it can be said that they want to form physical and mental bonds to create a happy, harmonious, and eternal family. Understanding the marriage law needs to be done with humanist efforts and cannot be done instantly. The efforts to understand the marriage law need to be made to all levels of society, especially for school children so that the marriage they live in can be in accordance with the objectives of the marriage. School children are classified as immature and they still have an important responsibility to study. They really need information about the marriage law in order to gain a comprehensive understanding of marriage because they are in a stage of growth that is full of curiosity. This program aims that school children will not get missed-information about the marriage law. Therefore, school students are one of the targets of this program.

Keywords: Marriage Law; Millennial Era; Student

\section{How to cite:}

Pujiono, P., Hidayat, A., \& Sulistianingsih, D. (2021). Understanding and Litera Legis of Marriage Law in the Milenial Era for School Children. Indonesian Journal of Advocacy and Legal Services, 3(2), 183-194. https://doi.org/10.15294/ijals.v3i2.45878 


\section{P. Pujono, A. Hidayat, \& D. Sulistianingsih}

\section{A. Introduction}

Marriage is a very important institution in society. The existence of this institution is to legalize the relationship between a man and a woman ${ }^{1}$. The concept of marriage law is important to understand comprehensively with the aim of avoiding divorce and the realization of a harmonious life in the family. The essence is to form a happy and eternal family in which husband and wife help and complement each other, so that each can develop their personalities, help and achieve spiritual and material well-being.

Marriage is the final journey that legalizes the relationship between a man and a woman in one family bond. It will form a new family of two parties (a woman and a man) which will later become a complete family. It is a physical and mental bond between a man and a woman as husband and wife with the aim of forming a happy and eternal family (household) based on The One and Only God.

Every human being in a society has a sacred view of marriage. In the increasingly complex society, it is understood that marriage is not just a personal romantic statement or religious ritual, but it is a public legal act that is governed by law and has legal consequences in life. In Indonesia, a marriage is legal if it is carried out according to the law of each religion and belief and the most important thing is that it is recorded according to the prevailing laws and regulations.

Even though it is considered valid in religion or custom, a marriage that is carried out without the acknowlwdgement and supervision of the marriage officer and then it is not registered, has no legal force and is considered invalid based on the law. The Indonesian legal system does not recognize the term "underhand marriage" or marriage based on religious rules and its kind and does not specifically regulate in the regulation. However, sociologically, this term is given to marriages that are not registered and are deemed to have been carried out without complying with the provisions of the applicable law, particularly regarding marriage registration as regulated in the Marriage UU Article 2 Paragraph $2^{2}$. In the marriage laws and regulations in Indonesia, the existence of the principle of marriage registration is related to determining the legality of a marriage, meaning that in addition to following the provisions of each respective law of religion or belief, it is also a condition

1 Salim HS, Pengantar Hukum Perdata Tertulis (BW), (Jakarta: Sinar Grafika, 2006), page 61

2 Djamilah, D., \& Kartikawati, R. (2014). Dampak perkawinan anak di Indonesia. Jurnal Studi Pemuda, 3(1), 1-16. DOI: https://doi.org/10.22146/studipemudaugm.32033 
of the validity of a marriage. Therefore, recording and making a marriage certificate is an obligation in the marriage laws and regulations in Indonesia.

Marriage is legal if it is carried out according to the law of each religion and belief; and in addition, every marriage must be recorded according to the prevailing statutory regulations. The registration of every marriage is the same as the recording of important events in a person's life, for example, births, deaths that are stated in certificates, an official certificate which is also included in the registration list. Apart from that, the marriage must also fulfill the legal requirements of marriage for the two couples who want to get married.

The validity of the marriage includes the agreement between the two prospective husband and wife. A person who has not reached the age of 21 must obtain permission from both parents. For women who have broken up their marriage, the waiting time applies. The prospective husband and wife must be at least 19 years old. The requirement for a marriage age limit of 19 years for men and women is based on UU No. 16 of 2019. Prior to UU No. 16 of 2019 is released, the minimum age requirement for marriage is 16 years for women and 19 years for men, this is based on UU No. 1 of 1974.

The change in norms in UU No. 1 of 1974 about Marriage extends the age limit for marriage. Improving norms reaches by increasing the minimum age of marriage for women. In this case, the minimum age of marriage for women is the same as for men, which is 19 (nineteen) years old. The age limit is considered to be mature in body and soul to be able to carry out a marriage in order to realize the goal of marriage properly without ending in divorce and getting healthy and quality offspring. It is also expected that an increase in the age limit of more than 16 (sixteen) years for women to marry will result in lower birth rates and reduce the risk of maternal and child deaths. Apart from that, children's rights can also be fulfilled so as to optimize children's growth and development, including mentoring parents and giving children the highest possible access to education.

The determination of the age limit for marriage is based on the following reasons: (1) Maintaining the health of husband and wife and their offspring; (2) Prevent child marriage; (3) Supporting family planning programs. These three reasons can actually represent the importance of determining the age limit of marriage.

Child marriage is a dilemma. Such cases are rare or very few, but in fact there are many cases of child marriage throughout Indonesia, generally due to the strong influence of customary law. Child marriage is a marriage 


\section{P. Pujono, A. Hidayat, \& D. Sulistianingsih}

performed by men and women who are still children ${ }^{3}$. A child in the legal category is a person who is not yet an adult.

In the scope of Human Rights Law on Child Protection, it is stipulated that a child is someone who has not reached the age of 18 , including children who are still in the womb, and have never been married. The age before 18 years is the age for school children, generally that age is at the middle or high school level. The age of school children or students is when they are looking for as much information as possible and absorbing that information. This requires good assistance or supervision related to information absorbed by school children (students).

One of the information absorbed by school children is information about the marriage law. Understanding the marriage law needs to be done with humanist efforts and cannot be done instantly. Efforts to understand the marriage law need to be made for all levels of society, especially for school children who are the younger generation so that the marriage they live in can be in accordance with the objectives of the marriage.

Young people really need information about the marriage law in order to gain a comprehensive understanding of marriage because they are in a stage of growth that is full of curiosity. This program aims that school children will not get missed information about the marriage law.

School age is basically the stage of growth and development. School students are classified as young people who have relatively unstable personalities and are looking for their identities. In this age, it is important to provide understanding and knowledge of various fields so that students are ready to enter a complex life.

Information and understanding of the marriage law for school children is very important, not only for their provisions when they are about to get married but also to prevent early marriages or marriages that have not met the minimum age limit for marriage. In this millennial era, all information is easy to obtain, children (young people) must be able to filter the information that is useful for themselves and their lives.

\section{B. Method}

This paper is the result of a program that has been carried out by the author team and several team support members. This program aims to provide legal understanding and literature (reading law well), especially in the study of

3 Musfiroh, M. R. (2016). Pernikahan Dini dan Upaya Perlindungan Anak di Indonesia. Jurnal De Jure: Jurnal Hukum dan Syari'ah, 8(2). DOI: https://doi.org/10.18860/j-fsh.v4i1.2151 
marriage books. It begins with filling in the initial questionnaire (pretest) and ends with filling in the final questionnaire (posttest) as part of the evaluation or feedback. This program aims to provide school students with knowledge and understanding of marriage law in Indonesia. In addition, this program also aims to prevent underage marriages or child marriages.

\section{Result and Discussion}

The marriage law in Indonesia adheres to the following principles: (1) marriage aims to form a happy and eternal family; (2) a marriage is legal if it is carried out according to the religious law; (3) marriages must be recorded according to statutory regulations; (4) marriage based on open monogamy (in this case it is possible to do polygamy); (5) a husband and wife candidate must be mentally and physically ready for the marriage; (6) The age limit of marriage for men and women is 19 years; (7) Divorce is complicated and must be done before a court session; (8) The rights and positions of husband and wife are fair. These principles are merged into the legal requirements of marriage which must be obeyed by those who are going to get married.

Provisions regarding marriage law need to be learned so that people will not only know but also understand their rights and obligations as citizens in marriage law. Reading laws and regulations is not only in the "letter lijk" way, but there are also several ways to read the law, which is by interpretation. This method of reading is called litera legis.

Litera legis is not an easy thing to do, especially for school children, especially to understand the marriage law. There are many things that must be understood by the school children so that they will not misunderstand the marriage law.

Marriage is a right, but apart from that there are obligations that are borne by the married couple, and this must be understood so that unwanted things will not occur, such as: domestic violence, divorce, husbands who do not support their wives, extravagant wives, and so on.

\section{Litera Legis in UU No. 16 of 2019 about Amendments to UU No. 1 of 1974}

UU No. 16 of 2019 is a law that was born by making changes and improvements to UU No. 1 of 1974 about Marriage. Not all articles in UU No. 1 of 1974 are amended by UU No. 16 of 2019 . The change is only to the age limit requirements for marriage. In UU No.1 of 1974, the legal age limit for marriage is a minimum of 16 years for women and 19 years for men. In UU 


\section{P. Pujono, A. Hidayat, \& D. Sulistianingsih}

No. 16 of 2019, the age limit for marriage is 19 years for both women and men.

Determining the age limit for marriage is not without reason, with many considerations, especially to prevent early marriage, for the mental readiness of potential partners, and preparation in terms of reproduction for women. Marriage at the age of children has a negative impact on the development of children and will cause the basic rights of children to be not fulfilled, such as the right to protection from violence and discrimination, children's civil rights, health rights, education rights, and children's social rights.

Child marriage is very likely to threaten and have a negative impact on children, including children's health, because the ideal reproductive maturity limit has not been reached. Not only health problems, marriages that have not exceeded the age limit of children are very likely to exploit children and increase the threat of violence against children. Child marriage will have a negative impact on children's education ${ }^{4}$. In order to realize a good marriage without ending in divorce and to get healthy offspring, underage marriage must be prevented ${ }^{5}$.

Prevention of early marriage is very important for society, especially for adolescents today. Apart from being beneficial for them, it is also useful for avoiding negative views from society. Prevention of early marriage also wants to create a young generation who is aware of education. Basically, getting married is indeed the privacy of the family. But in education, we are aware of what we have to do. In the prevention of early marriage, the community and adolescents are encouraged to have awareness to increase human resources optimally through education ${ }^{6}$.

Marriages that are carried out below the specified age limit are a form of violation of the existing provisions of the marriage law. It is called underage marriage or also commonly known as early marriage. Some of the impacts that can occur for perpetrators of underage marriage ${ }^{7}$ :

4 Hamzah. (2019). Telaah Maqasid Syariah Terhadap Putusan MK NO. 22/PUU-XV/2017 Tentang Batas Usia Nikah. AL-SYAKHSHIYYAH: Jurnal Hukum Keluarga Islam dan Kemanusiaan, 1(1), 61-84.

5 Suhaili, A. (2018). Relevansi Batas Usia Perkawinan Dalam Membentuk Keluarga Sakinah. Al-Bayan: Jurnal Ilmu al-Qur'an dan Hadist, 1(1), 92-120.

6 Prayono, A. R. A. A. (2016). Menciptakan Generasi Muda tanpa Pernikahan Dini di Kabupaten Situbondo. In Forum Ilmu Sosial (Vol. 43, No. 2, pp. 169-175). DOI: https://doi.org/10.15294/fis.v43i2.9357

7 Ilma, M. (2020). Regulasi Dispensasi dalam Penguatan Aturan Batas Usia Kawin bagi Anak Pasca Lahirnya UU No. 16 Tahun 2019. AL-MANHAJ: Jurnal Hukum dan Pranata Sosial Islam, 2(2), 133-166. https://doi.org/10.37680/almanhaj.v2i2.478 
1. Education impact. Children who marry at an early age will lose the right to education.

2. Biological and health impacts. Biologically, the reproductive organs of underage women are still in the stage of maturity, so they are not ready for sexual intercourse, pregnancy, and childbirth.

3. Psychological impact. Underage couples generally lack mental readiness to face domestic roles and problems.

4. Economy impact. The majority of young people who do not have a stable income or do not have a decent job are one of the problems in household life.

5. Social impact. From the social perspective, underage marriage also has the potential to increase the divorce rate.

Seeing this phenomenon, it is necessary to carry out understanding and litera legis for school children (the younger generation) regarding the marriage law. School children are classified as children aged 5 to 18 years. Before 19 years, they are not eligible for marriage. This understanding must be done as early as possible. School children have a fairly high educational load and can receive information and insights about the marriage law which will be very useful for their future.

The tasks of the educators today are more complex. In accordance with the mental characteristics of young people who are in the stage of searching for identity, the task of educators is to create the best possible environment by providing a lot of positive activities so that young people do not fall into negative activities that are detrimental to their future. Education for young people is carried out for self-control so that they do not fall into negative things. The education model at a young age is carried out to instil discipline, honesty, respect, respect and mutual help in all activities.

Schools as formal educational institutions have an important role to provide understanding and knowledge so that students are ready to play a role in the society. This role is not only providing important knowledge to be given as a scientific substance but also other knowledge that will be needed by students to enter social life. The school load is very large, of course, if you see this condition, there is a need for efforts to help the school provide knowledge and insight about the law that is not provided comprehensively by the school. Socialization and assistance in providing understanding (litera legis) to school children must be carried out to achieve the expected goals.

\section{Marriage Law Impact}

Marriage does not merely bind the relationship between one man and woman, but has very broad consequences not only for the perpetrator of the 


\section{P. Pujono, A. Hidayat, \& D. Sulistianingsih}

marriage but also for the children from the marriage, family, community, and the country ${ }^{8}$. Marriage is a legal act that will have legal consequences for both parties and other related parties. In Indonesia, the marriage law is regulated in UU No. 1 of 1974 about Marriage. UU No. 1 of 1974 was changed to UU No. 16 of 2019 about Amendments to UU No. 1 of 1974 about Marriage.

The consequences of a marriage have quite broad dimensions, including social and legal, starting at the time of marriage, during marriage, and after marriage. In a marriage, many things will happen or will be obtained such as; the problem of property, descent, where if there are no clear provisions, especially the problem of distribution of inheritance from the deceased or the divorcee, including the matter of their respective assets will cause a problem ${ }^{9}$.

Basically, a marriage that is carried out will have legal consequences, namely: (1) The emergence of a relationship between husband and wife; (2) The appearance of property in marriage; (3) The emergence of a relationship between parents and children. Actually, a marriage between a woman and a man will have a good impact on the children or offspring.

The marriage certificate becomes authentic evidence of an implementation of marriage so that it can be become a "legal guarantee" if a husband or wife commits an deviant act. For example, if a husband did not provided the living cost that has become his obligation, while in fact he is capable, or the husband violates legal provisions, the injured wife can file a lawduit in court. In addition, the marriage certificate also serves to prove the legality of the child from the marriage, so that without the certificate, legal proceedings to court cannot be carried out ${ }^{10}$.

The marriage that occurs will result in the emergence of a relationship between husband and wife. Husband and wife relationship includes rights and obligations in the household. The rights and position of husband and wife are fair in both household life and social interactions, so that everything in the family can be negotiated and decided together by husband and wife ${ }^{11}$.

The legal consequence of marriage will also lead to regulations regarding assets in marriage. Marriage assets are assets that are obtained individually or collectively as long as there is a marriage bond, and hereinafter referred to

8 Khosyi'ah, S. (2016). Akibat Hukum Perkawinan Tidak Dicatat Terhadap Istri Dan Anak Atas Hak Kebendaan Menurut Hukum Islam Di Indonesia. Asy-Syari'ah, 18(2), 185-200.DOI: https://doi.org/10.15575/as.v18i2.659

9 Azrianti, S. (2017). Analisa Yuridis Perjanjian Perkawinan Dan Akibat Hukum Bagi Para Pihak Berdasarkan Kompilasi Hukum Islam Dan Undang-Undang Nomor 1 Tahun 1974 Tentang Perkawinan. PETITA, 1(2).

10 Tantu, A. (2013). Arti Pentingnya Pernikahan. Al-Hikmah Journal for Religious Studies, 14(2), 199-208.

11 Komariah. (2008). Hukum Perdarta. Malang: UMM Press, page 42 
as joint assets, without considering under anyone's name ${ }^{12}$. With the existence of marriage, the assets generated during the marriage become joint assets of husband and wife regardless of who produced the assets, whether husband or wife, these assets remain joint assets of husband and wife.

Marriage has legal consequences for the rights and obligations of husband, wife, children, and guardianship and also affects property. Therefore, it is necessary to have legal awareness between husband and wife of the responsibilities given based on the applicable law so as to create a harmonious relationship in a marriage as the ideals and goals are noble as the basis for forming a happy household. .

Marriage that occurs between husband and wife forms an identity called family. Family is a form of legal bonding between man and woman through marriage. From this bond are born offspring who are legally the responsibility of the husband and wife or the mother and father in fostering and developing them. The result of marriage also results in a relationship between parents and children. Husband and wife, who are bound in a marriage and have children, have an obligation towards that child. The obligation of parents to children is to take care of their children as well as possible until they reach adulthood or be able to live independently. This obligation remains in effect even if the parents' marriage breaks up or ends.

\section{Conclusion}

Litera legis on marriage law for school children is carried out not only by reading UU No. 1 of 1974 which has been amended into UU No. 16 of 2019, but school children as the next generation of Indonesian must understand and interpret the marriage law well. The reason is none other than the achievement of the marriage goal, which is happiness in a harmonious family. Socialization and assistance in litera legis is very necessary and schools will really need assistance from other parties who have a better understanding of the law ${ }^{13}$. The legal consequences of marriage will create a relationship between husband and wife and will result in property in the marriage and the relationship between parents and children ${ }^{14}$. Legal consequences arise because of a legal relationship that occurs, in this case when a marriage occurs there is a legal relationship between husband and wife. Such a legal

12 Mustafa, A. (2019). Analisis Gender Terhadap Harta Benda Perkawinan Dalam UUP Nomor 1 Tahun 1974. Al-Risalah Jurnal Ilmu Syariah dan Hukum, 19(1), 90-96.

13 Sanger, J. P. (2015). Akibat Hukum Perkawinan Yang Sah Didasarkan Pada Pasal 2 UU. Nomor 1 Tahun 1974 Tentang Perkawinan. Lex Administratum, 3(6).

14 M Yusuf, M. Y. (2014). Dampak Perceraian Orang Tua Terhadap Anak. Jurnal AlBayan: Media Kajian dan Pengembangan Ilmu Dakwah, 20(1) 
relationship will have legal consequences, namely in the form of rights and obligations that must be carried out by both parties.

\section{E. Acknowledgments}

This article was created due to funding from the Faculty of Law, Universitas Negeri Semarang. Thank you to the Head of the Faculty of Law, Universitas Negeri Semarang and the parties involved in this program.

\section{F. Declaration of Conflicting Interests}

The authors states that there is no conflict of interest in the publication of this article.

\section{G. Funding}

Universitas Negeri Semarang, Indonesia.

\section{H. References}

Act No 16 of 2019 about Amendment to Act No 1 of 1974 about Marriage Act No. 1 of 1974 about Marriage.

Azrianti, S. (2017). Analisa Yuridis Perjanjian Perkawinan Dan Akibat Hukum Bagi Para Pihak Berdasarkan Kompilasi Hukum Islam Dan Undang-Undang Nomor 1 Tahun 1974 Tentang Perkawinan. PETITA, 1(2).

DOI: http://dx.doi.org/10.33373/pta.v1i2.689

Djamilah, D., \& Kartikawati, R. (2014). Dampak perkawinan anak di Indonesia. Jurnal Studi Pemuda, 3(1), 1-16. DOI: https://doi.org/10.22146/studipemudaugm.32033

Hamzah. (2019). Telaah Maqasid Syariah Terhadap Putusan MK NO. 22/PUU-XV/2017 Tentang Batas Usia Nikah. AL-SYAKHSHIYYAH: Jurnal Hukum Keluarga Islam dan Kemanusiaan, 1(1), 61-84.

Ilma, M. (2020). Regulasi Dispensasi dalam Penguatan Aturan Batas Usia Kawin bagi Anak Pasca Lahirnya UU No. 16 Tahun 2019. $A L$ MANHAJ: Jurnal Hukum dan Pranata Sosial Islam, 2(2), 133-166. https://doi.org/10.37680/almanhaj.v2i2.478

Khosyi'ah, S. (2016). Akibat Hukum Perkawinan Tidak Dicatat Terhadap Istri Dan Anak Atas Hak Kebendaan Menurut Hukum Islam Di Indonesia. Asy-Syari'ah, 18(2), 185 200.DOI: https://doi.org/10.15575/as.v18i2.659

Komariah. (2008). Hukum Perdata. Malang: UMM Press 
M Yusuf, M. Y. (2014). Dampak Perceraian Orang Tua Terhadap Anak. Jurnal Al-Bayan: Media Kajian dan Pengembangan Ilmu Dakwah, 20(1).

Musfiroh, M. R. (2016). Pernikahan Dini dan Upaya Perlindungan Anak di Indonesia. Jurnal De Jure: Jurnal Hukum dan Syariah, 8(2). DOI: https://doi.org/10.18860/j-fsh.v4i1.2151

Mustafa, A. (2019). Analisis Gender Terhadap Harta Benda Perkawinan Dalam UUP Nomor 1 Tahun 1974. Al-Risalah Jurnal Ilmu Syariah dan Hukum, 19(1), 90-96.

Prayono, A. R. A. A. (2016). Menciptakan Generasi Muda tanpa Pernikahan Dini di Kabupaten Situbondo. In Forum Ilmu Sosial (Vol. 43, No. 2, pp. 169-175). DOI: https://doi.org/10.15294/fis.v43i2.9357

Salim HS. (2006). Pengantar Hukum Perdata Tertulis (BW). Jakarta: Sinar Grafika

Sanger, J. P. (2015). Akibat Hukum Perkawinan Yang Sah Didasarkan Pada Pasal 2 UU. Nomor 1 Tahun 1974 Tentang Perkawinan. Lex Administratum, 3(6).

Suhaili, A. (2018). Relevansi Batas Usia Perkawinan Dalam Membentuk Keluarga Sakinah. Al-Bayan: Jurnal Ilmu al-Qur'an dan Hadist, 1(1), 92-120.

Tantu, A. (2013). Arti Pentingnya Pernikahan. Al-Hikmah Journal for Religious Studies, 14(2), 199-208 


\title{
Culture is no excuse for abuse
}

\author{
Davinder Kaur
}

FORCED TO MARRY HIM: A Lifetime of Tradition and the Will to Break It

\section{ABOUT AUTHOR(S)}

Dr. Pujiono, S.H., M.H. is a Lecturer at Department of Private and Commercial Law, Universitas Negeri Semarang. Some of his recent publications such as Permodalan Bagi Usaha Mikro, Kecil Dan Menengah Di Kabupaten Batang (Jurnal Pengabdian Hukum Indonesia, 2019), Implementation of Certification of Processing Feasibility (CPF) of Processed Milkfish Products in Indonesia (Economic and Social of Fisheries and Marine Journal, 2018), and Law and Ethics of Communication in Social Media (Jurnal Dinamika Hukum, 2017).

Arif Hidayat, S.H., M.H., is a Lecturer at Department of Administrative and Constitutional Law, Universitas Negeri Semarang. He also a Doctoral Student at Universitas Islam Sultan Agung Semarang. Some of his recent publications such as Politik Hukum Legislasi Sebagai Socio-Equilibrium Di Indonesia (Jurnal Ius Constituendum, 2019), and The Ideal Relationship between Legal Knowledge and Actual Legal Actions in Indonesia (Proceedings on International Conference on Indonesian Legal Studies, 2019).

Dr. Dewi Sulistianingsih, S.H., M.H., is a Lecturer at Department of Private Law, Faculty of Law Universitas Negeri Semarang, Indonesia. Some of her recent publications such as Disaster resilient village-based approach to disaster risk reduction policy in Indonesia: A regulatory analysis (Jàmbá: Journal of Disaster Risk Studies, 2021), and fungsi Dan Kedudukan Perjanjian Berbentuk Pactum De Compromittendo Dalam Sengketa Hak Kekayaan Intelektual (Jurnal Meta-Juridis, 2020) 